неионообменных взаимодействий между матрицей и поляризуемыми ионами. Такая особенность этого материала обеспечивает получение ионообменников с более высокой эффективностью по сравнению с ионообменниками на полимерных носителях. В то же время нельзя забывать о том, что ионообменники на основе силикагеля можно использовать только в диапазоне $\mathrm{pH}=2 \div 10$. Если рассматривать применение таких ионообменных метериалов в хроматографии, то они могут быть использованы только в одноколоночном варианте [5].

Однако перспектива разработки принципиально новых материалов даёт более широкую возможность применения ионного обмена, а также создание новых технологий в разделении растворов.

\section{Список литературы}

1.Нойман Штефан. Применение ионообменных смол для водоподготовки и очистки сточных вод промышленных предприятий - 2011 г. // Вода: химия и экология, - № 5 стр. 40-45.

2.Смирнова Е.Е., Кисель А.В., «Ионообменная хроматография. Общие сведения и понятия» - 2019 г. // Международный научный журнал «ВЕСТНИК НАУКИ», № 3 (12) Т.3, - С. 80 - 89.

3.Pohl C.A. Recent Developments in IonExchange Columns for Ion Chromatography // LC-GC Eur. 2013. V. 31. P. 16-22.

4.Кольцов С. И., Алесковский В. Б. Силикагель. его строение и химические свойства. Госхимиздат, Л., 1963.

5.Методы получения высокоэффективных неподвижных фаз для анионообменной хроматографии / А. В. Затираха, А.С.Ужель, А.Д. Смоленков, О.А. Шпигун // Вестник Московского университета. Сер. 2, Химия. - 2018. - Т. 59, № 1. C. 3-19

УДК: 621.391

ГРНТИ: 28.21.15, 28.29.03

\title{
CONTROL OF THE DYNAMICS OF A COMPLEX SYSTEM
}

DOI: $10.31618 /$ ESU.2413-9335.2019.5.69.498

Ismailov Bahram Israfil

PhD, docent, Department of Instrumentation Engineering, Azerbaijan State Oil and Industry University, Baku, Azerbaijan Republic, orcid.org/0000-0002-5815-1253

\section{УПРАВЛЕНИЕ ДИНАМИКОЙ СЛОЖНОЙ СИСТЕМЫ}

\author{
Исмайлов Бахрам Исрафил \\ К.т.н., дочент кафедры "Приборостроительная Инженерия”, \\ Азербайджанский Государственный Университет Нефти и Промышленности, \\ Баку, Азербайджанская Республика.
}

\section{ABSTRACT}

The article is devoted to the analysis and control of the development of dynamic processes in multidimensional chaotic systems. The research scheme is presented and the rationale for the methods used is given. According to the research algorithm, on the example of interactions of a system consisting of interconnected objects, the features of controlling their dynamics in the framework of the Open System are shown. The results of analytical and numerical modeling of the system behavior during interaction in the interference field and the possibility of controlling its dynamics are presented in graphical form. As an example, in the identified areas of interest of the researcher, the results of calculations of informative parameters, such as Poincare diagrams, Tsallis entropy, Lyapunov exponents, stability indices, fractal dimension are shown. The main informational and dynamic characteristics of the process under study allow us to visually evaluate its behavior and choose an impact control strategy that is satisfactory to the researcher.

\section{АННОТАЦИЯ}

Предлагаемая вниманию статья посвящена вопросам анализа и управления развитием динамических процессов в многомерных хаотических системах. Представлена схема исследований и дано обоснование используемых методов. Согласно алгоритму исследования, на примере взаимодействий системы, состоящей из взаимосвязанных объектов показаны особенности управления их динамикой в рамках Открытой Системы. В графической форме представлены результаты аналитико-численного моделирования поведения системы при взаимодействии в поле помех и возможности управления её динамикой. В качестве примера, в выделенных областях интереса исследователя, показаны результаты вычислений информативных параметров, таких как диаграммы Пуанкаре, энтропия Цаллиса, показатели Ляпунова, показатели стабильности, фрактальная размерность. Основные информационные и динамические характеристики исследуемого процесса позволяют нам визуально оценить его поведение и выбрать удовлетворяющую исследователя стратегию управления воздействием. 
Keywords: chaotic processes, hyperchaotic systems, Poincare recurrence, Tsallis entropy, Lyapunov exponent.

Ключевые слова: хаотические процессы, гиперхаотические системы, рекуррентность Пуанкаре, энтропия Цаллиса, показатель Ляпунова.

Predicting the dynamics of complex systems is an urgent problem related to the assessment of its evolution. The interaction of objects in the Open System leads to an increase in chaotic processes, as a result of which one can observe a state of dynamic chaos in it. The phase portrait of the processes under study allows us to present the parameters of a dynamic system and to trace the change in their behavior caused by the influence of control actions, mutual influence, noise effects, etc. [1-5].

Control of the development of chaos in nonlinear dynamical systems is of practical importance. The process of influencing a system with a chaotic character is based on the phenomenon of the sensitivity of chaotic systems to small disturbing influences, as a result of which a new system can be obtained with parameters satisfying the intended purpose [6].

In contrast to traditional methods for analyzing complex processes, the nonlinear recurrence analysis proposed by Poincare, as well as the obtained recurrence diagrams, allow one to study and predict the behavior of the system using discrete mapping [7-10].

In addition, the use of nonlinear recurrence analysis allows, using a limited amount of data, to adequately analyze the process and present it in the form of a discrete recurrence diagram. The visual features of the recurrence diagram are its topology, texture and color palette of points located on the square matrix - traces of the intersection of the process path in phase space with the secant plane $[8,9,11]$. Such attributes of the recurrence diagram allow, through visual thinking, to interpret the nature of the process under study, its development trend, to study in detail the areas of interest, to reveal hidden features, etc. $[8,9,11]$.

An important informative indicator of chaotic complex self-organizing systems is entropy. In the study of transient and recurrent processes in multidimensional chaotic systems of fractional order, entropy oscillations $[4,10,12]$ are of considerable interest. Unlike traditional methods, the Tsallis entropy is preferred for evaluating the results of interactions of heterogeneous chaotic fractional systems. The core of the issue is the thermodynamics of Tsallis, which leads to a statistical physics not Boltzmann type: individual particles with Boltzmann statistics + strong interactions $\Rightarrow$ new degrees of freedom with no Boltzmann statistics + lack of interaction [13].

The proposed indicator has both theoretical and practical significance for the description of complex systems $[14,15]$.

Tsallis entropy has the form [13]:

$$
S_{\tilde{q}}=-\sum_{i}\left(P_{i}^{\tilde{q}} \ln _{g}\left(P_{i}\right)\right)=\left(1-\sum_{i} P_{i}^{\tilde{q}}\right) /(\tilde{q}-1)(1)
$$

where $\tilde{q}$ - measure is not extensiveness of the system and can take a value: $-\infty:+\infty, i$ - systems status number, $P_{i}$ - the probability of finding the system in state $i, \Sigma_{i}$ - summing over all states.

Let's consider the interconnected information objects interacting within the framework of the Open System. An example research scheme for studying the behavior of interacting systems is presented in Figure 1.

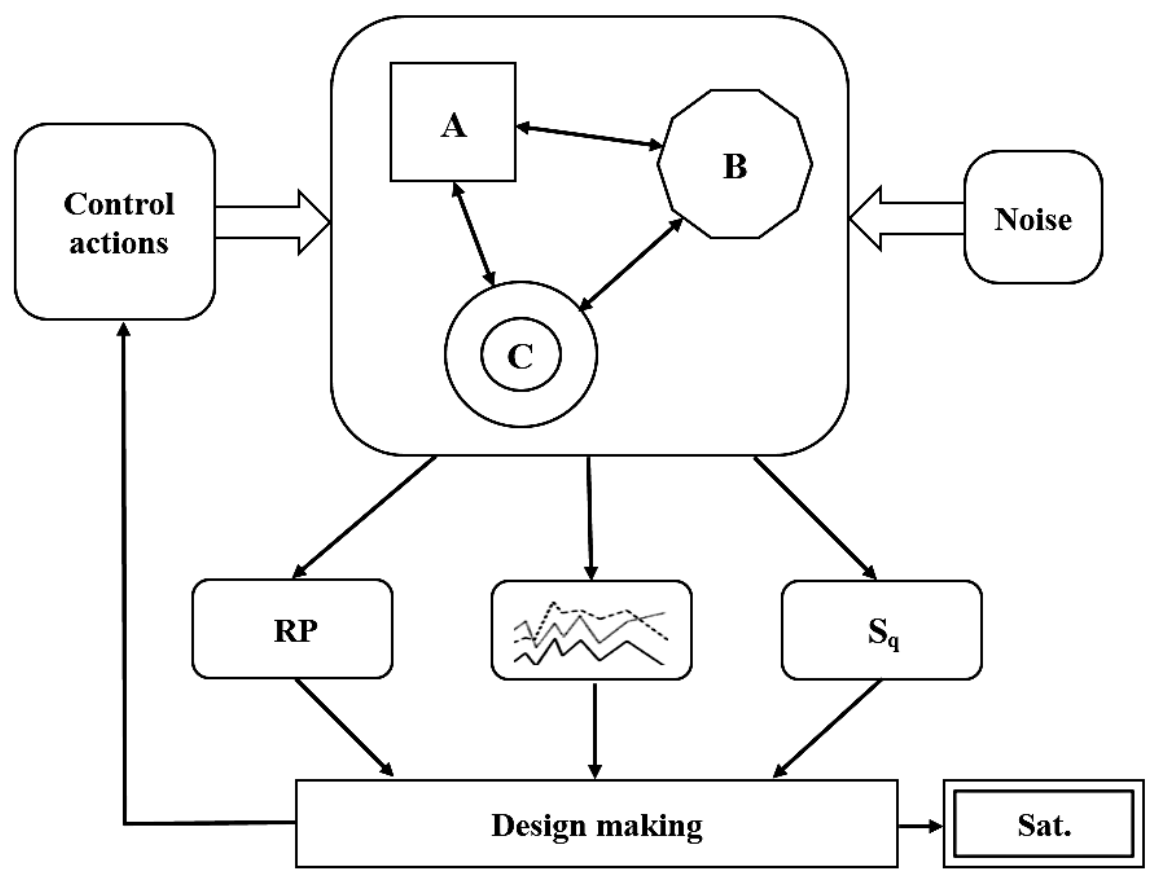

Figure 1. The structure of the study of the interactions of information objects, the management of their behavior, state analysis and decision making. 
Presentation of interacting systems

As an example of interacting systems, the following were chosen:

A - Chen's hyperchaotic system following [16]:

$$
\begin{aligned}
& D_{x_{1}}^{q_{1}}=a_{1}\left(x_{2}-x_{1}\right)+x_{4}, \\
& D_{x_{2}}^{q_{2}}=\gamma x_{1}-x_{1} x_{3}+c_{1} x_{2}, \\
& D_{x_{3}}^{q_{3}}=x_{1} x_{2}-b_{1} x_{3}, \\
& D_{x_{4}}^{q_{4}}=x_{2} x_{3}+d_{1} x_{4},
\end{aligned}
$$

where $q_{1}=q_{2}=q_{3}=q_{4}=0.95$, the system parameters are $\left(a_{1}, b_{1}, c_{1}, d_{1}, \gamma\right)=(35,3,28,7)$.

B - Rabinovitch-Fabricant Fractional-order Rabinovich-Fabrikant system following [17]:

$$
\left.\begin{array}{l}
\dot{x}_{1}=x_{2}\left(x_{3}-1+x_{1}^{2}\right)+\gamma x_{1}, \\
\dot{x}_{2}=x_{1}\left(3 x_{3}+1-x_{1}^{2}\right)+\gamma x_{2}, \\
\dot{x}_{3}=-2 x_{3}\left(x_{1} x_{2}+\alpha\right) \\
\dot{x}_{4}=-3 x_{3}\left(x_{2} x_{4}+\delta\right)+x_{4}^{2},
\end{array}\right\}
$$

where $\alpha=0.14, \gamma=1.1,-0.01 \leq \delta \leq 7650$.

C - The four-dimensional integral-order hyperchaotic fractional Liu system [18]:

$$
\left\{\begin{array}{l}
\frac{d^{\alpha} x}{d t^{\alpha}}=a(y-x), \\
\frac{d^{\alpha} y}{d t^{\alpha}}=-k x z+b x+\vartheta, \\
\frac{d^{\alpha} z}{d t^{\alpha}}=d x y-c z, \\
\frac{d^{\alpha} \vartheta}{d t^{\alpha}}=-h y,
\end{array}\right.
$$

where $\quad a=10, b=40, c=2,5, d=4, h=$ $5, k=1$ and $\alpha=0.9$.

As a control action, we apply fractional Levy flight $[19,20]$.

The mathematical model of fractional Levy traffic will be expressed as [19]:

$$
\tilde{A}=m t+(\bar{\sigma} m)^{1 / 2} L_{\alpha, H(t)},
$$

where $m>0-$ is the mean input rate, $\bar{\sigma}$ is the scale factor, and $L_{\alpha, H(t)}$ is the fLm (fractional Levy motion) process.

Classical chimeric states are paradigmatic examples of partial synchronization schemes that arise in nonlinear dynamics. The state of the chimera is an intriguing and contradictory spatio-temporal state that has been and is at the center of active research over the past decade [21,22].

\section{Research algorithm}

Step 1. Figure 2 shows the resulting signal of interactions and interactions of chaotic systems Chen, Rabinovich-Fabrikant and Liu:

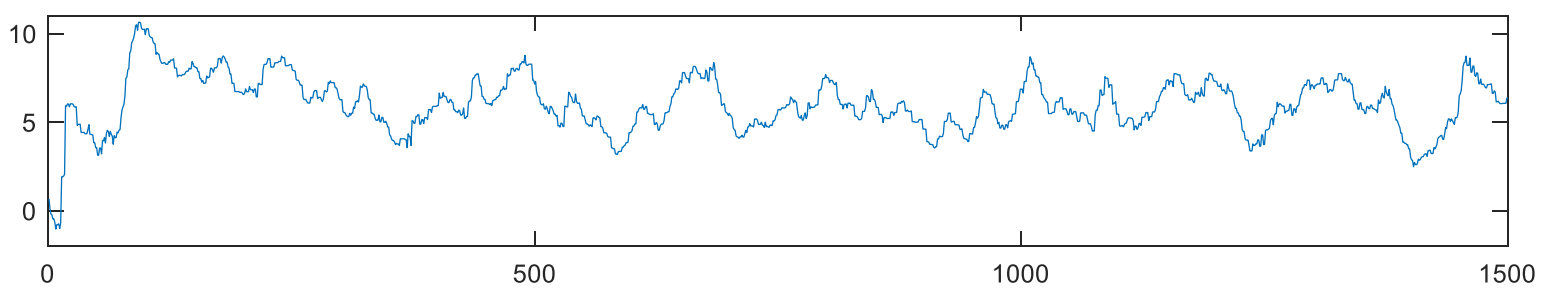

Figure 2. Signal of coupled systems.

Step 2. The effect of Noise and Control action is shown in Figure 3:

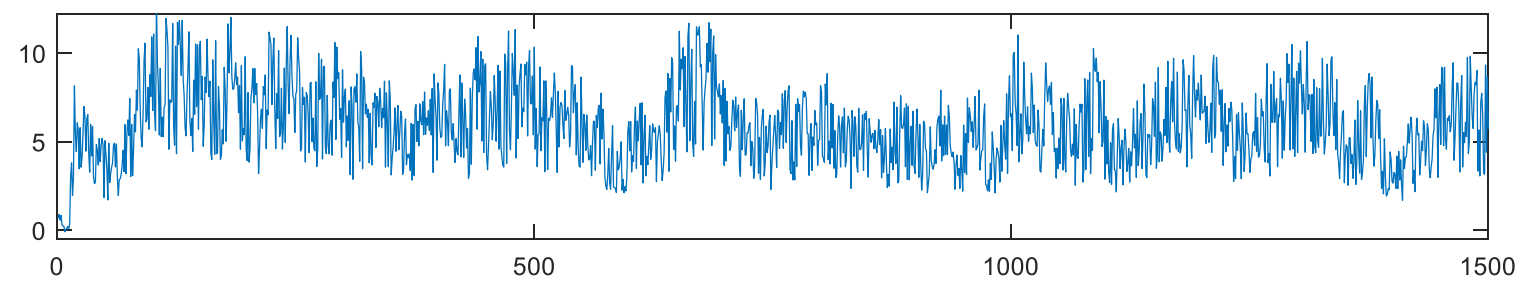

Figure 3. Result of control and noise influence.

The Poincare diagram of the resulting signal of the interactions of related systems and the influence of the noise impact of Chimera and the corrective effect of Levi flight on their dynamics are shown in Figure 4: 


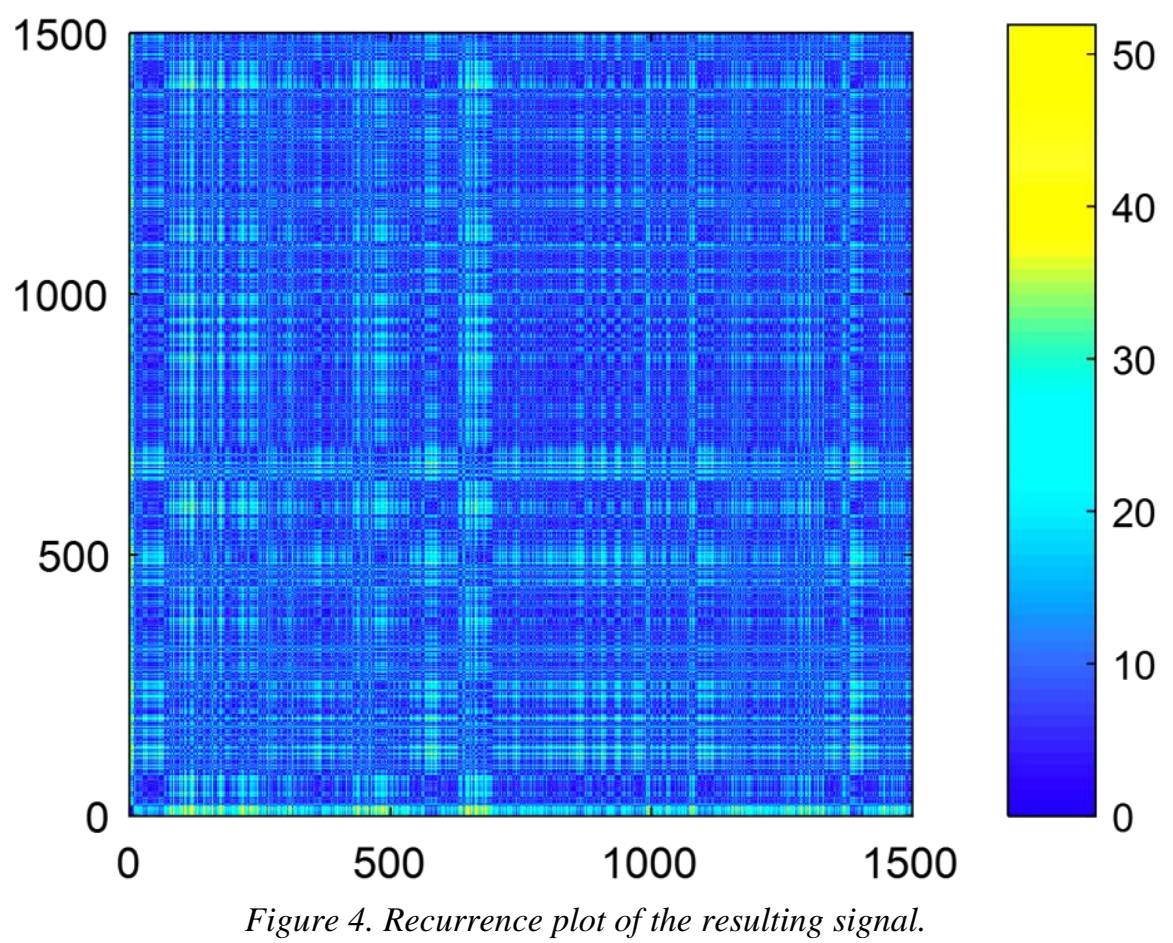

Step 3. An example of the selection of areas of features of the structure of the recurrence diagram interest by a decision maker on the characteristic Figure 5:

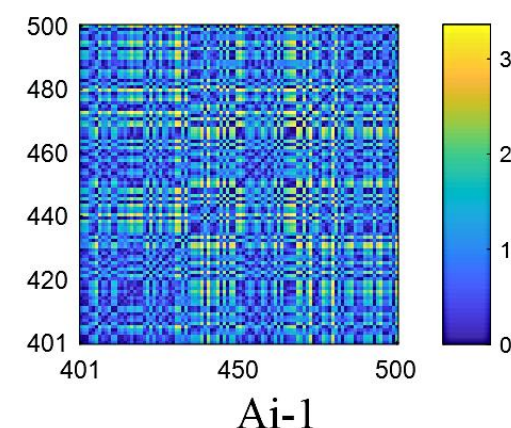

Ai-1

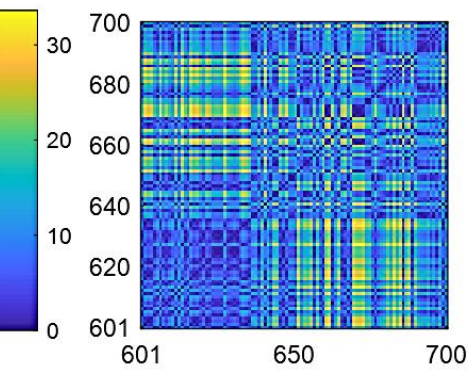

Ai-2
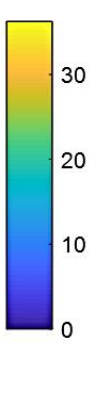

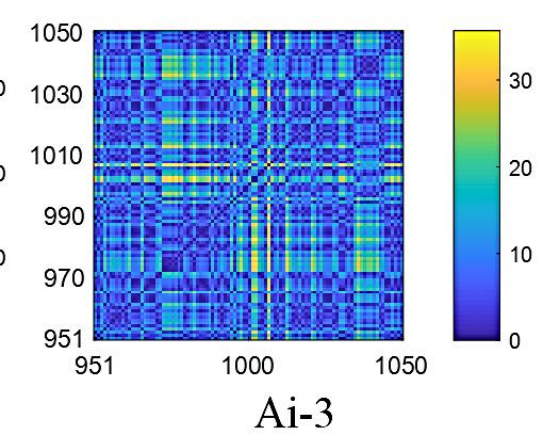

Ai-3

Figure 5. An example of the selection of areas of interest according to the characteristic features of the recurrence diagram.

Step 4. Calculation and demonstration of interest), such as - Tsallis entropy, Lyapunov exponent informative parameters of the selected AI (areas of and Stability indicator: 


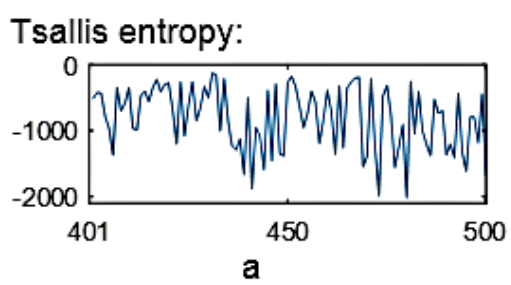

Lyapunov exponent:
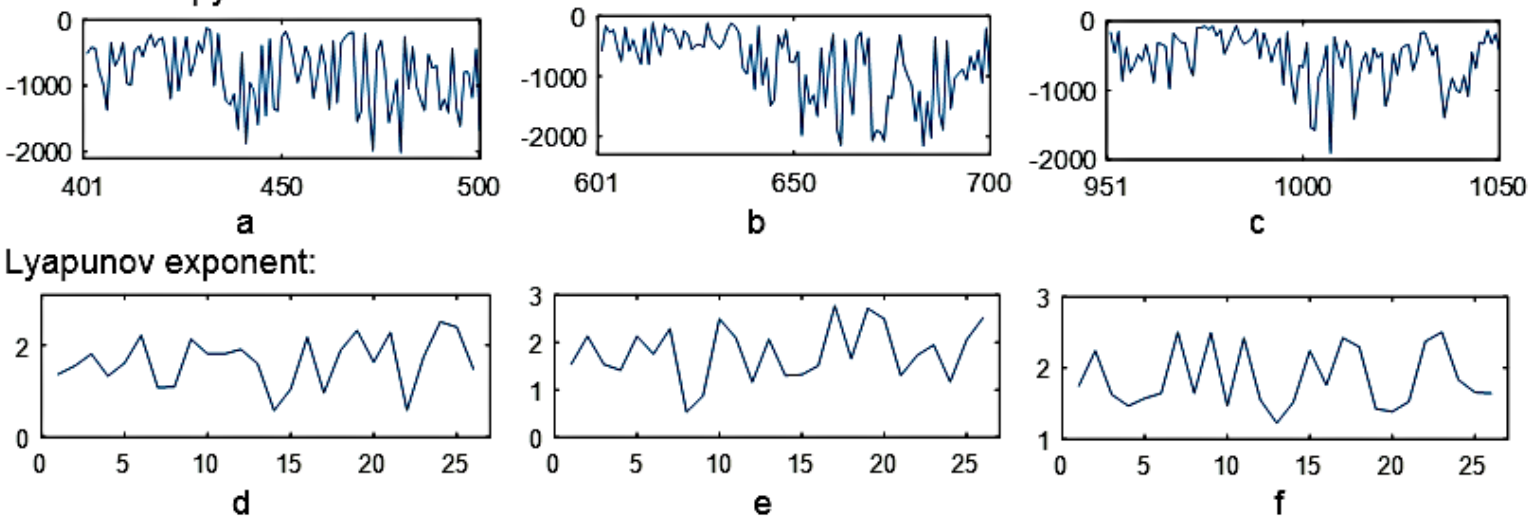

Stability:
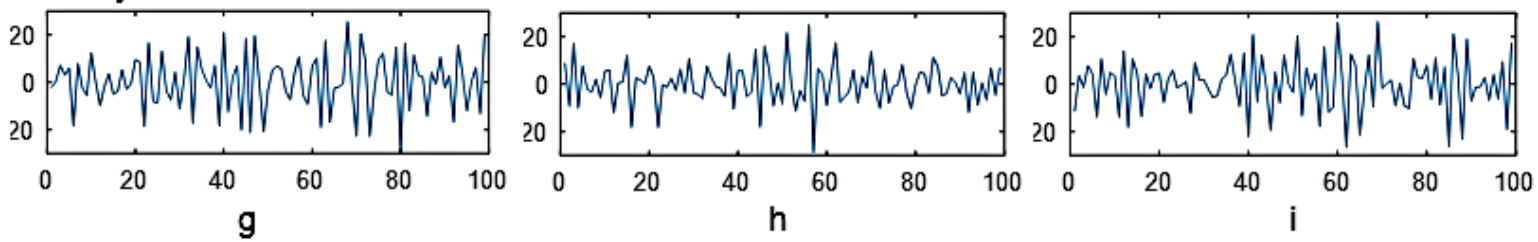

Figure 5. Calculation of informative parameters:

$a, d, g$ - for AI-1, b, e, $h$-for AI-2, c, f, I-for AI-3.

Step 5. For each selected AI, we calculate the fractal dimensions:

$$
\mathrm{D}_{\mathrm{Ai}-1}=1.6275 ; \mathrm{D}_{\mathrm{Ai}-2}=1.5559 ; \mathrm{D}_{\mathrm{Ai}-3}=1.6036 \text {. }
$$

The choice of control actions, as well as the allocation of areas of interest for modeling the research process is made by the researcher based on his reflective choice [23]

\section{Conclusion}

The example of analysis of interactions of chaotic systems presented in the article is accompanied by visualization of the stages of the research and is aimed at acquainting the reader with the possibilities of numerical modeling.

The information component of the analysis of the state of the system under study includes the Tsallis entropy, Lyapunov exponent, stability index, fractal dimensions, and can be supplemented by the researcher.

The proposed approach to the analysis of the behavior of interrelated objects allows, through the assessment of the dynamic indicators of the new structure, to make a decision on the choice of control actions to obtain a mode satisfying the requirements of the researcher.

\section{References}

1.Sprott J.C., Chaos and Time Series Analysis, Oxford University Press, Oxford, 2003. 507p.

2.Grigorenko I. and Grigorenko E. (2003). Chaotic dynamics of the fractional Lorenz system. Physical Review Letters, 91 (3): 034101. https://doi.org/10.1103/PhysRevLett.91.034101.

3.Ibedou I. and Miyata T. (2008). The theorem of Pontrjagin-Schnirelmann and approximate sequences. New Zealand Journal of Mathematics, 38: pp. 121-128.

4. Vladimirsky E.I., Ismailov B.I. Transient and recurrence processes in open system. International
Journal of Advanced and Applied Sciences (IJAAS), 4(10) 2017, pp.106-115.

5. Ismailov B.I. Analysis Simulation of Interaction Information in Chaotic Systems of Fractional Order. International Journal of Engineering and Applied Sciences (IJEAS). 2017. Vol.4, issue 6. pp.85-91.

6. Ismailov B.I. Poincare recurrence in open systems. Journal of Multidisciplinary Engineer in Science and Technology (JMEST). Vol. 3, ISSUE 9, 2016. Pp. 5565-5569.

7.Poincaré H. (1890) Sur la problem des trois corps et les équations de la dynamique. Acta Mathematica. 13: pp. 1-271.

8.Eckman J., Kamphorst S., Ruelle D., Recurrence Plots of Dynamical Systems, Europhysics Letters, 4 (9), 1987. Pp. 973-977.

9.Webber C.L., Zbilut J.P. Recurrence quantification analysis of nonlinear dynamical systems. Chapter 2. In: Riley MA, Van Orden G (eds) Tutorials in contemporary nonlinear methods for the behavioural sciences, pp. 26-92 https://www.nsf.gov/pubs/2005/nsf05057/nmbs/nmbs. pdf. Accessed 5 July 2018.

10.Ismailov B.I. Thermodynamic - Informational Paradigm in the Context of the Formation of a Mathematical Model of Transient Processes in an Open System. European Journal of Engineering Research and Science Vol. 2, No. 10, 2017. pp. 17-20.

11.Bruce Hobbs and Alison Ord. Nonlinear dynamical analysis of GNSS data: quantification, precursors and synchronization. Progress in Earth and Planetary Science. 2018. 35p.

12. Liu J and Teel AR. Hybrid systems with memory: modelling and stability analysis via generalized solutions. IFAC Proceedings, 2014. Volumes, 47(3): 6019-6024.

13. Tsallis C. and Ugur Tirnakli. Nonadditive entropy and nonextensive statistical mechanics- some 
central concept and recent applications. Journal of Physics: Conference Series 201. 2010. - pp. 1-16.

14. Ismailov B.I. Analysis and Control of Dynamic Processes in Mechanical Parts of Power Equipment. International Journal of Mechanical and Production Engineering Research and Development (IJMPERD). 2018. Pp. 347-352.

15. Vladimirsky E.I., Ismailov B.I. Physics of Open System. Non-standard approaches in the context of studies of multidimensional coupled chaotic systems of fractional order. International Conference on Recent Innovations in Electrical, Electronics \& Communication Engineering (ICRIEECE), IEEE Bhubaneswar Subsection. India. 2018. Pp. 229-230.

16. Hegari A.S., Matouk A.E. Dynamical behaviors and synchronization in the fractional order hyperchaotic Chen system. Applied Mathematics Letters 24, 2011. Pp. 1938-1944.

17. Srivastava M. and all. Chaos control of fractional order Rabinovich-Fabrikant system and synchronization between chaotic and chaos controlled fractional order Rabinovich-Fabrikant system. Applied Mathematical Modelling. Volume 38, Issue 13, 1 July 2014, Pp. 3361-3372.

18. Han Qiang, SunLei, Zhu Darui, Liu Chongxin. A four-dimension fractional order hyperchaotic system derived from Liu-system and its circuit research. http://www.paper.edu.cn

19. Laskin N., Lambadaris I., Harmantris, Devetsikiotis M. Fractional Levy Motion and Its Applications to Network Traffic Modeling. [Text]. // Computer Networks, vol. 40, issue 3, 2002. Pp. 363375. Doi $>10.1016 /$ S1389-1286(02)00300-6.

20. Dubkov A.A., Spagnolo B., Uchikin V.V.. L'evy Flight Superdiffusion: An Introduction. Bifurcation and Chaos. September 2008. DOI: 10.1142/S0218127408021877 · Source: DBLP.

21. Kuramoto Y. 1975. Self-entrainment of a population of coupled non-linear oscillators. Int. Symp. on Mathematical Problems in Theoretical Physics (Lecture Notes in Physics) ed $\mathrm{H}$ Araki (Berlin: Springer) pp. 420-422.

22. Murray Shanahan. Metastable chimera states in community-structured oscillator networks. Chaos 20, 013108. 2010.

23. Vladimirskiy E.I. Otobrazhenie printsipov refleksii $\mathrm{V}$ matematicheskoy modeli prinyatiya udovletvoritelnyih resheniy. Tr. IV Mezhd. Konferentsii «Identifikatsiya sistem i zadachi upravleniya», SICPRO'05. Moskva 25-28 yanvarya 2005. M.: Institut problem upravleniya im. V.A.Trapeznikova RAN. 2005. Pp. 1681-1688.

УДК 664.723

ГРНТИ 65.29.29

\title{
МОДЕЛИРОВАНИЕ КИНЕТИКИ ДВУХСТУПЕНЧАТОЙ ПРЯМОТОЧНОЙ СУШКИ ЗЕРНА
}

DOI: $\underline{\text { 10.31618/ESU.2413-9335.2019.5.69.499 }}$

Малин Николай Иванович

д-р техн. наук, профессор

Федеральное Государственное бюджетное образовательное учреждение высшего профессионального образования «Российский государственный аграрный университетМосковская сельскохозяйственная академия имени К.А. Тимирязева», Россия, г. Москва

\section{MODELING OF THE KINETICS OF TWO-STAGE DIRECT-FLOW GRAIN DRYING}

\author{
Malin Nikolay Ivanovich \\ dr tech. sciences, professorship \\ Federal state budget educational institution of higher education \\ «Russian state agrarian university- \\ Moscow Timiryzev agricultural academy», Russia, Moscow
}

\section{АННОТАЦИЯ}

Отмечено, что в условиях двухступенчатой сушки, используемой в шахтных прямоточных зерносушилках, во вторую ступень (иначе, - во вторую зону сушки), поступает зерно с частично обезвоженной поверхностью и повышенной, в сравнении с начальным значением, температурой. Поэтому при описании кинетики двухступенчатой сушки возникают проблемы с использованием кинетических зависимостей, используемых для описания одноступенчатой сушки. Предложена и описана процедура моделирования кинетики двухступенчатой сушки зерна. Приведены примеры (с графическим сопровождением) практической реализации процедуры моделирования, показавшей достаточную для инженерных расчетов надежность.

\section{ABSTRACT}

It is noted that in the conditions of two-stage drying used in direct-flow mine dryers, in the second stage (otherwise, in the second drying zone), grain comes in with a partially dehydrated surface and an increased temperature in comparison with the initial value. Therefore, when describing the kinetics of two-stage drying, problems arise with the use of the kinetic dependences used to describe one-stage drying. A procedure for modeling the kinetics of two-stage drying of grain is proposed and described. Examples are given (with graphic support) of 